\title{
Transitividades nos Circuito e Cenários das Festas Espetáculos Populares
}

\section{Transitivity in circuits and scenarios of popular spectacular festivals}

Edson Farias ${ }^{1}$

Resumo: Neste artigo, o ponto de partida é a compreensão da festa como situação descomprometida com as questões candentes da vida cotidiana. Porém, o que se procura argumentar é o quanto as festas espetáculos podem ser perspectivadas pela capacidade de viabilizar trânsitos entre as esferas política e cultural. Para isto, leva-se a sério a natureza mesma de diversão desses acontecimentos. A organização do percurso narrativo da análise está dividida em duas partes. Na primeira, retoma-se o carnaval carioca visando encontrar nele a matriz da festa espetáculo no Brasil e, no seu interior, o advento de uma modalidade de espaço-ritual mundano diversional com forte poder de conferir visibilização pública. Já, na segunda parte, o recurso à noção de mimese sensório-cromática terá por finalidade expor os trâmites e mecanismos acionados no tipo de reflexividade social promovido nos cenários lúdico-estéticos das festas espetáculos populares, que ora compõem um circuito lúdico do entretenimento.

Palavras-chaves: Transitividades; Circuitos do entretenimento; Cenários lúdico-estéticos; festas-espetáculos populares.

Abstract: In this article, the starting point is the understanding of the party as situation of disengagement towards the burning duties of everyday life. It is examined, however, to what extent these performative parties can be

\footnotetext{
${ }^{1}$ Pesquisador de Conselho Nacional de Pesquisa - CNPq. Professor adjunto do Departamento de Sociologia da Universidade de Brasília e do Programa de Pós-Graduação em Memória: Sociedade e Linguagem da Universidade Estadual do Sudoeste da Bahia. Líder do grupo de pesquisa Cultura, Memória e Desenvolvimento (CMD/UnB); editor da revista Arquivos do CMD.
}

Latitude, Vol. 10, no 1, pp. 134-153, 2016

DOI: https://doi.org/10.28998/2179-5428.20160107 
viewed from the perspective of their potentiality to facilitate transits between the political and cultural spheres. With this aim, their very nature of the entertainment event is taken seriously. The narrative of the analyses is organized in two parts. The first part returns to Rio's carnival seeking to identify in it the matrix performative parties in Brazil, and, in its context, the advent of a mundane amusement ritual-venue with strong power to grant public visibility. In the second part, the use of the concept of sensorychromatic mimesis is meant to expose the procedures and mechanisms set off in the kind of social reflexivity that the recreational and aesthetic scenarios of popular performative parties promote, which make up an entertainment circuit nowadays.

Keywords: Transitivity; entertainment circuits; recreational and aesthetic scenarios; performative festivals.

Conversas do dia a dia, em acordo com o conteúdo de publicidades, matérias jornalísticas e, inclusive, enunciados eruditos, propagam uma compreensão consagrada sobre os circuitos das grandes festas populares no Brasil, hoje: a opinião solidificada em certeza de que, manifestações de evasão da rotina diária, nesses momentos extraordinários a diversão generalizada dispensa aspectos afins do tempo da seriedade. Consequentemente, em sua carnavalidade exaltando os excessos sensualistas (gastronômicos, etílicos, sexuais, sobretudo), tais festivais ou esfumam tudo quanto seria prioritário no andamento rotineiro da vida ou, no máximo, dramatizam apenas para gerar o zombeteiro efeito irreverente provocador do riso, da alegria descontraída. Passada a momentânea intensidade sensitiva evocada e promovida pela ilusão imaginativa da brincadeira, restaria voltar ou se deparar com enfrentamentos que estiveram suspensos.

A concepção acerca da sucessão de episódios subjacentes à compreensão descrita sumariamente, aqui, ergue-se sobre dois postulados básicos sinalizando o que prescreve determinada epistemologia da festa $\mathrm{e}$ sua normatividade. De um lado, a festa popular atualiza e torna profana a densidade espaciotemporal inerente à delimitação das interdições de que são alvo os objetos do sagrado. De outro, essa interdição circunscreve à festividade teores desprovidos de tudo quanto seja relativo à luta pela 
Transitividades nos Circuito e Cenários das Festas Espetáculos Populares

sobrevivência. Logo, desprendida dos pesos ordinários da política e da economia, sobra-lhe a leveza, mesmo a frivolidade leviana da diversão.

Neste texto não temos por objetivo interrogar, tampouco discordar dessa epistemologia; o que se procura argumentar é o quanto as festas espetáculos podem ser perspectivadas pela capacidade de viabilizar trânsitos entre as esferas política e cultural. Isto, levando a sério a natureza mesma de diversão desses acontecimentos. A organização do percurso narrativo da análise está dividida em duas partes. Na primeira, voltamos ao carnaval carioca visando encontrar nele a matriz da festa espetáculo no Brasil e, no seu interior, o advento de uma modalidade de espaço de visibilização pública. Já na segunda parte, o recurso à noção de mimese sensório-cromática terá por finalidade expor os trâmites e mecanismos acionados no tipo de reflexividade social promovido nos cenários lúdicoestéticos das festas espetáculos populares, nesse circuito do entretenimento.

\section{Carnaval, matriz de um ritual mundano diversional}

As brincadeiras carnavalescas, sob o nome de "Dias Gordos", chegaram ainda no início da conquista portuguesa na América do Sul. Porém, diferente do que ocorreu na metrópole europeia, no Brasil, os festejos se restringiram às cidades. Nelas, sob a denominação de entrudo e integrada ao calendário católico, a festa pagã alcançou segmentos sociais os mais diversos, incluindo escravos e mulheres, embora sem negligenciar hierarquias e estratificações sociais (QUEIROZ, 1992, p.10-25). No decorrer de 500 anos, em especial durante o século XX, a folia momêsca encontrou um lugar estratégico no delineamento da cultura e da identidade nacionais. Sua ritualidade ancorou traços exaltados do perfil do país e de seu povo: o sensual estilo tropical com apreço ao comportamento lúdico de uma alegria irreverente. Não é de se estranhar o fato de ter se consagrado um signo de brasilidade com circulação mundial.

Justamente por sua abrangência, vazando as dimensões continentais do Brasil, capaz de atravessar estratificações de classe, raça, gênero, idades e outras, o carnaval se firmou como uma festa nacional por excelência. Entronada nesse posto, consolidou-se amplo espaço de visibilidade composto pelos mais diferentes gestos, linguagens e códigos, enfim. Assim, informada por todos esses suportes simbólicos e expressivos, há tempos a festa compõe uma esfera pública plebeia na qual a promessa de ver e ser 
Edson Farias

visto, fazendo comuns nomes, ideias e comportamentos, atrai os mais distintos interesses, permite consensos e/ou fermenta conflitos, mesmo se torna palco de guerras de valores. Muito emblemático a esse respeito fora a tentativa de grupos burgueses de implantar um modelo único de festejar, entre a metade do século XIX e as primeiras décadas do século XX, no Rio de Janeiro.

Então capital nacional e principal centro urbano brasileiro, o transporte do modelo inspirado nas folias de Paris e Nice para essa cidade esteve motivado pelo projeto de civilizar a população brasileira. Ou seja, de fazer um padrão de comportamento pacífico no tocante à presença das pessoas e grupos no espaço público. A civilização viria à medida que as principais vias daquele centro urbano fossem tomadas pelos desfiles de grandes carros alegóricos onde estariam personalidades das classes abastadas e seus (e suas) apaniguados (as); peças móveis que estariam dotados de suficientes recursos cênicos para encantar os olhos de populares acomodados na posição de plateia a serem ilustrados (PEREIRA, 2005). Os passos da história deixaram em xeque o projeto burguês, quanto à pretensão de homogeneizar os comportamentos sob o imperativo do seu quadro de valores. $\mathrm{O}$ modelo de desfile se propagou pela cidade e gerou consequências imprevistas como as escolas de samba. Instituição referida às classes populares, mais propriamente aos descendentes de grupos humanos até o final do século XIX submetidos aos grilhões da escravidão (FARIAS, 2006).

O projeto civilizatório burguês e suas repercussões não planejadas evidenciam como a esfera pública no Brasil, nos dois últimos séculos, estivera submetida à questão nacional. Mas, igualmente, deixa ver como a folia teve relevância na afirmação do conceito de nação miscigenada e no delineamento desse lugar de visibilidade. Cabe observar que se desenhou uma ordem de enunciados aninhada nos círculos do pensamento social e do jornalismo em que o carnaval se confundiu com a ideia e a imagem de Brasil, no compasso mesmo em que o destacou pelos atributos de espaço de visibilidade pública. De acordo com essa ordem, movido pelo princípio de comunhão, a razão da sua "autenticidade" fundada no imperativo da coesão, os festejos carnavalescos são saudados pela pretensa capacidade de congregar ludicamente grupos distintos. Quem melhor sintetizou essa discursivização foi o antropólogo Roberto Da Matta (1973). Segundo ele, apoiada em sua base popular, a festa carnavalesca ritualizaria o plano dos 
Transitividades nos Circuito e Cenários das Festas Espetáculos Populares

valores possíveis em uma sociedade complexa, afinal permitiria a essa tanto promover sua identidade social quanto elaborar seu caráter no momento em que instaura a prerrogativa do todo sobre a parte, isto é, da submissão do individual ao coletivo. Ressalta, então, a força do carnaval em transferir para impessoalidade da rua à afetividade dos laços da casa (Da Matta, 1981, p. 38). Algo possível com a inversão temporária das hierarquias sociais, a qual seria responsável pela abolição das cesuras (Da Matta, 1985, p. 92).

Na última década, sem perder o foco do espaço de visibilidade pública, uma considerável alteração se deu na ordem discursiva sobre a folia carnavalesca no Brasil. Ainda que não se negligencie os temas afins tanto do nacional quanto do povo-nação, a ênfase recai cada vez mais na envergadura universal do festejo, porque estaria fundada sobre valores e aspirações básicas de toda humanidade. $\mathrm{O}$ objeto por excelência dessa revisão tem sido os formatos e volumes discrepantes entre si com os quais os diversos grupos humanos intensificam a tomada de ruas, praças e avenidas em diferentes áreas do Rio de Janeiro, para brincar o carnaval. Em 2013, segundo a prefeitura da cidade, o contingente de brincantes teria sido de cinco milhões de pessoas, distribuídos em mais de 450 grupos de desfilantes, muitos denominados "blocos" e outros "bandas" (MOTTA, 2013). Algo distinto do período compreendido entre os anos de 1980 e 2000, quando muitas vozes se levantaram para decretar (e lamentar) a "morte do carnaval de rua" da cidade. Muitos são os intérpretes que enxergam na situação um "renascimento" da alma irreverente e galhofeira da folia momêsca; alma que teria se ausentado dos desfiles das principais escolas de samba - o evento de maior repercussão no interior da festa carioca. O também antropólogo José Sávio Leopoldi argumenta que o "renascer da carnavalidade" na festa carioca com os blocos estaria na contrapartida da novidade dessas unidades em reintroduzir uma margem maior de liberdade natural aos atos humanos. A seu ver, algo assim seria peculiar a países à maneira do Brasil, pois ainda guardam amplas zonas da dimensão não oficial, pela largueza das suas expressões culturais populares. A reserva de tradição os tornaria atrativos para turistas residentes em outras sociedades nacionais em que em que tais parcelas foram demasiadamente reduzidas devido ao "manto da civilização ultrarregrada" (LEOPOLDI, 2010, p. 40). 
Contudo, afirma o autor, os nativos brasileiros, em especial os cariocas, estariam desconfortáveis com as modalidades já enrijecidas de carnaval, sobretudo com, as escolas de samba, em razão da elevada formalização dos comportamentos que passou a dominá-las. O advento dos blocos de rua seria o retorno a uma "liberdade impensável" nos dias comuns; liberdade manifesta nos atos provocativos e licenciosos frente à hegemônica moralidade vigente. Se for inegável que os traços da vida oficial permanecem atuantes na organização da folia promovida pelos blocos, ainda assim, para o antropólogo, nela palpita e aflora vigorosa aquela "primitividade" visceral. Ele conclui estar o potencial de globalização da festa popular promovida pelos blocos de rua na possibilidade concretizar uma essência primitiva humana, selvagem mesmo, a qual teria sido domesticada pela intensificação do processo civilizador em outras sociedades, nos recentes séculos (Op. cit., p. 44).

Devido ao compromisso com a posição de crítica cultural à modernidade, enunciados à maneira desses costumam acentuar os traços a favor de valores como o da autenticidade, em detrimento de todos os demais envolvidos com dispositivos de regulação do comportamento humano. Sem entrar no mérito a respeito da existência ou não desta "essência primitiva", negligencia-se o fato de os grupos adquirirem formatos de procissões nas manifestações de rua, fato este que já subentende a existência, mesmo que tácita, de normas atuantes na ordenação do comportamento dos participantes. Mas é importante sublinhar que, para além do constrangimento exercido pelos órgãos estatais de segurança pública, tanto os excessos nos atos licenciosos quanto o emprego da brutalidade entram em choque com as expectativas geradas em torno da brincadeira. Ambas os padrões de atitudes são detratados e coibidos em nome do imperativo categórico de uma atmosfera ordeira de paz, em grande medida, consensualizado entre os diferentes planos de produção, organização e participação na festa. As vendas de cotas de patrocínio por parte da prefeitura municipal para grandes empresas, como indústrias de cerveja e bancos, estão na contrapartida dessa mesma crença na segurança para os que se divertem. Lastreada em igual certeza, as redes de hotéis e operadoras turísticas promovem a folia internacionalmente, visando atrair clientes. Logo, o princípio da civilidade e, com ele, algum gabarito de refreio aos impulsos primários, não é externo ao convite de compor à espaciotemporalidade extraordinária da festa. 
Transitividades nos Circuito e Cenários das Festas Espetáculos

Populares

A tônica na atitude pacífica deixa entreve mais um desdobramento não programado do projeto civilizatório burguês, no Brasil, na atual retomada das ruas por essas massas sempre maiores de pessoas. Mas é o próprio entendimento do carnaval como um grande ritual mundano de diversão o que chama atenção às maneiras historicamente imprevistas como costumes festivos e civilização urbana moderna se entrecruzaram no Rio de Janeiro. Se a inversão tal como descrita e analisada por Bakhtin (1993), em que a individualidade evanesce em meio o êxtase popular, ao se apossar dos logradouros públicos da Europa medieval, é substituída pela experiência da procura individualizada da euforia (MOURA, 2013, p.3138 ), os rituais mundanos diversionais compreendem domínios móveis em que a busca do gozo no deleite do bem-viver é animada pela consciência acerca da condição perecível da existência. Logo, se as passeatas lúdicas e expressivas carnavalescas se impõem pela capacidade que demonstram de aliar ritmos e corporalidades, elas guardam semelhança com outras pelo envolvimento presencial entre expressão e fascínio, a exemplo daquelas exibidas em grandes eventos esportivos (GUMBRECHT, 1987, p109-149.).

Esteve na contrapartida das metamorfoses organizacionais, em que o lúdico-estético deslocou o étnico-religioso, o processo pelo qual o carnaval carioca se materializou em grande ritual mundano e, assim, compôs espécie de vitrine à exposição pública de emoções e na vulgarização das imagens de indivíduos e grupos. Desde o século XIX, nessa cidade, emerge uma mesma matriz cultural a partir da transformação dos folguedos sincréticos de base rítmico-percussiva (chamados de cucumbis). Embora com vínculo religioso reverente aos santos católicos e entidades divinas referidas à África prédiaspórica, o formato processional surgido (sob a denominação "ternos") era híbrido, na medida em que se mesclavam a elementos laicos, em especial, doses de irreverência manifestas nos trajes. Começava-se a deixar margens mais largas para inventividade e criação pessoal. Então, os grupos compostos por negros e mestiços passavam a tomar as ruas da cidade no natal e no carnaval, durante o final do período colonial e o Império. Da mesma matriz, já na virada do XIX para o XX, surgem tanto os intrépidos cordões marcados pelo grau maior de informalidade comportamental (no tocante aos entendimentos dos hábitos "sérios" e "comedidos" de se apresentar em público) nos cortejos, inspiradores dos diversos tipos de blocos que ganharam evidência desde o último século, quanto os ranchos com sua 
característica cênico-dramatúrgica. Marca peculiar aos formatos de um e outro gênero cultural se manifesta no movimento das pessoas que entram e saem ou das que param, mas também daqueles que prosseguem durante as situações de desfile. Por serem hoje os mais visíveis herdeiros deste longo processo, os estilos de blocos de rua e escolas de samba consistem em coreografias de gestos cujas formas e figuras delineadas estão em resposta a estímulos rítmico-musicais vários, sempre devotadas à exibição pública. Suas marchas se dão com alternâncias entre escalas de maior ou menor tensão ou rarefação emocional, mas sempre obedientes à observação do critério da bela alegria nos hábitos de expressão. As margens admissíveis na gradação existente nesses mesmos movimentos é o que diferencia os formatos do desfiles-espetáculos e dos blocos e dos cordões (FARIAS, 2012, p.72-73).

A festa carnavalesca carioca se antecipou, sagrando-se matriz de características estruturais atualmente compartilhadas amplamente por diversas festas pelo Brasil, no instante em que adquirem o formato de grandes festivais de entretenimento (FARIAS, 2011, p.85-196). Nesses eventos, folguedos e mesmo gêneros musicais estão articulados com outros móveis culturais de passatempo; são reconhecidos pela mesma disposição em sensibilizar e informar os sentidos de uma vastidão de pessoas de grupos sociais também diversos (em termos socioeconômicos, étnicos, geracionais, de gênero, etários e sexuais). E, assim, passam a ostentar uma carga de significados que os consagra como espaços e tempos prioritários à realização da liberdade individual, da felicidade e da libertária exposição dos sentimentos. Sendo lugares onde, cada vez mais, as exposições públicas das emoções ocorrem no compasso da apropriação reflexiva e privada da cena coletiva, mas se dão articuladas com a afirmação de novas modalidades de controle coletivo e autocontrole. É preciso reconhecer que a participação nesses eventos de congraçamento popular se define em sintonia tanto com a profissionalização dos produtores culturais (artísticos ou não), quanto pela racionalização técnico-administrativa $\mathrm{e}$ comercialização dos serviços, em meio ao aumento nos comprometimentos com os comércios turísticos e da diversão. Sem esquecer a decisiva intermediação institucional exercida pelo ordenamento estatal de poder, em seus três níveis (local, estadual e federal), fornecendo meio financeiros a contratações de serviços necessários na montagem de infraestruturas espaciais (palcos, camarotes e arquibancadas, por exemplo) e de músicos, 
Transitividades nos Circuito e Cenários das Festas Espetáculos Populares

cenógrafos, designers, técnicos em áudio e som, entre os muitos profissionais da complexa teia própria à divisão do trabalho técnica mobilizada na realização dessas festas. Logo, também, na instalação de equipamentos de iluminação, sonoridade, alimentação, etc. Mas, igualmente, atua prestando serviços nas áreas de segurança, higiene, atendimento médico-ambulatorial, limpeza, divulgação, entre outras.

Portanto, internas às feições múltiplas e diversas do calendário festivo no Brasil, as festas espetáculos populares oferecem um repertório capaz de agradar diferentes gostos. Estendido ao longo dos doze meses do ano, na condição de marcador temporal, tal calendário, impõe-se sobre os ritmos da vida cotidiana, distribuindo-se em fases comemorativas à maneira do carnaval, semana santa, ciclo junino, natal e revellion. Orbitando em cada um desses períodos, como partes de um conjunto expressivo de cerimônias dotadas de finalidades, formatos, conteúdos, dimensões e esquemas organizacionais bem discrepantes entre si (CAVALCANTI, 2013, p.10-20), os grandes festivais populares de massa revelam, em seu microcosmo, dinâmicas sociohistóricas em que a triangulação nação, entretenimento e modernidade deteve posição estratégica na conformação contemporânea da sociedade nacional no Brasil. Do mesmo modo, os teores característicos dessas festividades são heurísticas de ressignificações em planos sociossimbólicos distintos na medida em que se consolida, no Brasil, a condição da sociedade de consumidores. Condição está posta no rastro do estabelecimento de novos parâmetros aos diversos regimes de práticas nos domínios das expressões e das comunicações. Reverberando, logo, nas formações subjetivas e nas interações. Ao mesmo tempo, incidindo ainda sobre as decisões acerca dos usos e igualmente na organização sociopolítica dos recursos materiais e simbólicos.

Em meio a essas transformações e novos ajustes, enquanto uma ampla esfera social na qual se tornam mútuos mercantilização, atividades de diversão, técnicas e equipamentos, além de nichos institucionais variados, o entretenimento parece se sagrar ao concatenar a dinâmica de lucratividade do capital com circuitos de produção e consumo de bens culturais e daí interagir com as lutas em favor da afirmação de identidades e atendimento de estimas individuais e coletivas (FARIAS, 2014, p.33-74). No mesmo diapasão, são estabelecidos vínculos entre atividades relativas a mercados como o das viagens e hospedagens e ainda das prestações de serviços lúdico-artísticos e das mídias com a mobilização de saberes e 
linguagens na evocação de memórias e patrimônios, mas na contrapartida de equilíbrios de poderes sincronizando ordenamentos locais, nacionais e transnacionais.

Os deslocamentos no quadro de valores e da arquitetura moral e normativa descritos contracenam com reorientações socioestruturais de ampla e profunda abrangência. Com o emprego da categoria urbanoindustrial e de serviços pretendemos tipificar, exatamente, a forma de um padrão societário resultante desses remanejamentos e diz respeito ao patamar societário no qual a industrialização ultrapassa a lógica produtivista e desenvolvimentista. E, assim, contracena com os complexos técnico-cognitivos nos quais a potencialização dos estoques de conhecimentos e suas mediações - a informação, enquanto fluxos binários de comandos - protagonizam o incremento da produção e reprodução tanto nas dimensões materiais quanto intangíveis, mas sob a égide da orientação monetário-financeira. Isto quer dizer estarem permuta e equivalência entre signos (e, portanto, não entre signos e coisas) inseridas na mesma dinâmica em que os âmbitos da diversidade bioétnico-societal, onde expressões cada vez mais se transformam em imagens sintonizadas ao comércio de informações, estão ajustados ao esquema fundado na lucratividade expansiva das relações socioeconômicas capitalistas na fundamentação da economia simbólica (FARIAS, 2007, p.127-152).

$\mathrm{Na}$ continuidade da argumentação desenvolvida, neste texto, o ritual mundano diversional das festas espetáculos populares é abordado da maneira como a emergência de um quadro de valores, cuja tônica recai na autenticidade dos sentimentos, favorece fóruns de exposições públicas de emoções. E, na contrapartida, pressionam-se estes mesmos fóruns no sentido de potencializarem ao máximo os meios de atendimento de estimas e satisfação de demandas afetivas. A pergunta que nos move é: essas festas refletem ou são reflexivas em relação às estruturas social e psicossimbólicas acima apresentadas?

\section{Cromatismos sensório-afetivos de rituais mundanos}

Nas últimas décadas, em especial, filósofos e sociólogos tem mostrado significativo interesse tanto pelo perfil hedonista do individualismo que emerge quanto pela cumplicidade estabelecida em um mesmo padrão cultural entre a ênfase no sensualismo e na informalidade 
Transitividades nos Circuito e Cenários das Festas Espetáculos

Populares

dos gestos com os protocolos referidos à fremência espetacular das imagens. Entre os pioneiros dessa discussão, Richard Sennett (1988) assinala o declínio da antropologia do homem público e do sujeito soberano devido à prioridade posta, sempre mais, na compulsão em trazer à cena do convívio comum as idiossincrasias individuais, suas intimidades, em detrimento da autocontenção como parâmetro do comportamento republicano, respaldado na preservação do bem coletivo. Ainda, para o autor, o traço ostentado por essa compulsão da cultura do "novo capitalismo" faz dueto com uma "política de consumo" movida pela "paixão autoconsuptiva". Esta deixaria, em seu rastro, desperdício e intemperança como resultantes de um esquema no qual a busca de cada vez maiores rendimentos é assistida pela devoção ao andamento, sem limites, dos gastos elevados (SENNETT, 2006, p.129).

$\mathrm{Na}$ contramão, outros intérpretes se esforçam para evidenciar o advento de um novo regime de subjetividade que acompanharia esse contexto sociohistórico, portanto, revelando possiblidades e constrangimentos inusitados aos agenciamentos pessoais e institucionais. Em particular, sublinham como a maior plasticidade conferida aos fóruns públicos estendeu as margens à visibilidade grupos com suas pautas, narrativas e símbolos até então deixados no escuro da história burguesa, ou seja, no plano invisível da intimidade. Logo, enxergam nesse entrosamento um dos fatores decisivos ao atual e grande reforço das lutas em favor do reconhecimento de identidades precarizadas - minorias étnicas, de gênero e sexuais. Nesse sentido, o aporte de Kellner (KELLNER, 1993, p.174-175) guarda uma interessante sugestão, ao relacionar as diversidades e heterogeneidades etnicohistóricas dos cenários metropolitanos com a confluência de forças, desenhando outro equilíbrio de poder em que o complexo informacional-comunicativo e suas implicações na circulação e consumo de bens culturais são investidos como arenas onde emulam novas agendas identitárias. Assim, por exemplo, os jogos de prazer e sedução postos na visibilidade cintilante das aparências estão aliados à atitude performática das narrativas individuais e dos grupos. $\mathrm{O}$ desempenho lúdico é o anverso possível de uma situação de alta complexidade e saturação, na qual a previsibilidade é substituída pela atuação mimética de dá-se relacionalmente e, daí, garantir limites efêmeros de reconhecimento. Tal sugestão reflexiva em relação às identidades, no entanto, reveste o tema da operacionalização de recursos pelas agências na constituição das 
identidades e estilos de um apelo liberal-democratizante, dando pouca atenção à maneira como diferença e desigualdade são termos aproximados na gramática de uma estrutura social que tem entre suas propriedades centrais a expansão do capital, entendida enquanto lógica de apropriação privada dos recursos coletivos. A ausência, exatamente, de atenção ao problema da estrutura atravessou muita das concepções inscritas nas correntes pós-modernistas. Estando estas últimas empenhadas mais em realçar as mediações e os exercícios reflexivos das agências.

Já na compreensão do sociólogo Scott Lash (1997), por exemplo, para além dos elementos cognitivos, nas redes informacionalcomunicativas flutua outra economia de signos e espaços, em que os símbolos mobilizados são miméticos. E do mesmo modo como os conceitos vinculados ao nexo poder-conhecimento da empresa supranacional (que modula a dominação capitalista tardia com a reflexividade possível), os sinais ativados pelos fluxos de imagens, sons e narrativas promovem também processos reflexivos, mas de característica estética e esta, no seu neotribalismo, adequaria o princípio básico do "individualismo expressivo" à estética, conformando uma possibilidade ética de moldes étnicos nas condições da sociedade de consumidores:

Esta disparidade - entre a aquisição das habilidades de processamento dos símbolos e o acesso ao fluxo dos símbolos nas estruturas I\&C, entre o acesso ao envio dos símbolos e a sua recepção - tem sido e continuará sendo cada vez mais uma mistura poderosa para a crítica política e cultural heterodoxa por parte dos negros, das mulheres, de outras minorias étnicas - das próprias "zonas selvagens" (Op. cit., p. 163).

Um conjunto outro de autores atenta mais à economia psíquica desse individualismo expressivo. Cas Wouters (2012, p. 546-570), por exemplo, volta originalmente ao legado eliasiano sobre as dinâmicas de transformações dos costumes, mediante etnografias históricas, ao enfatizar a relação estabelecida entre as problemáticas em torno do aumento no gabarito de autocontrole próprio aos processos civilizadores e os desideratos dos fenômenos de democratização funcional, em que é 
Transitividades nos Circuito e Cenários das Festas Espetáculos

Populares

observada a redução dos gradientes de desproporção na retenção de recursos simbólicos e materiais entre dominantes e dominados. Embora seja um aspecto que percorra a obra de Elias e adquire destaque tanto no tratamento dado pelo autor à Revolução francesa em $A$ Sociedade de Corte quanto à ascensão de Hitler e do nacional-socialismo em Os Alemães, Wouters o retoma a partir de certa passagem de O Processo Civilizador na qual os gestos intrínsecos à negação tanto do ascetismo quanto da procrastinação emblemáticos da ordem burguês-produtivista por parte da atitude contracultural, naturalista e vitalista dos Hippies são interpretadas, por Elias, a luz de um patamar bem elevado de autocontenção sintetizado no lema "paz e amor". O autor holandês sublinha o que a princípio seria um paradoxo, afinal, registra a intimidade histórica e eletiva estabelecida entre constrangimento e o que denomina de "informalização" dos comportamentos, ao longo do século $\mathrm{XX}$, sobretudo nas sociedades industrializadas do Ocidente. Cada vez mais, nota ele, desde a "revolução expressiva" da década de 1960, pessoas e grupos admitem viverem e experimentarem situações "perigosas" sem temerem por em risco suas respectivas dignidades. Embora não chegue conceituar a contrapartida socioestrutural da alteração no padrão emocional analisado, em lugar de supor um vácuo individualista de regulação, Wouters atenta para as condições de possibilidades sociohistóricas em que avança esta outra economia psíquica capaz de aliar incremento da autorregulação com a prerrogativa do prazer.

A existência das festas espetaculares populares em proporção tão avantajada, no Brasil, alerta à necessidade de evitar o translado e aplicação automáticos desses modelos analíticos elaborados a luz dos contextos das sociedades nacionais da Europa ocidental e da América anglo-saxã para outros hemisférios. Não porque estes estejam em descompasso, "atraso", e lhes faltem elementos essenciais para equipararem-se ao "mundo desenvolvido", onde se desenrola um exercício reflexivo que toma a própria modernização como objeto (BECK,1997). Argumentos assim, caudatários das fórmulas evolucionistas, seja substancial ou lógica, pouco ou nada tem a dizer sobre as características da diferenciação sociocultural relativas ao contexto analítico macrossocial das múltiplas faces da modernidade. Multifacetado, esse real-histórico se realiza em fenômenos como os focalizados neste texto que manifestam encontros culturais e interpenetrações civilizatórias alinhando, mesmo que tensamente, heranças 
africanas e ameríndias àquelas do catolicismo e, nestas, camuflando formas culturais pré-cristãs. Enlaces coloniais mais tarde vertidos para o inventário da cultura nacional e aos esquemas dos mercados ampliados de bens simbólicos, o que subsidiou a montagem desse circuito da economia do lúdico em que as festas espetáculos populares ocupam destacada posição.

A ideia mesma de informalização deve ser relativizada em uma experiência como a do Brasil, tendo em mente o curso dos séculos XIX e XX. País onde o traçado sempre hesitante da regulação estatal no emprego da violência na dimensão pública das relações sociais, aliado à exuberância da informalidade na regência das relações de trabalho e o coeficiente baixo de escolaridade formal da população, não contribuiu para a expansão de um modelo disciplinar fundado sobre a exigência de um padrão de acentuada autocontenção pública dos afetos. Na contrapartida, o desenho de um sistema de festas populares deu relevo às soluções de sociabilidade e coordenação social cujo destino teve por antecedente tanto a centralidade do poder localizado calcado na posse da terra quanto às feições tomadas pela cristandade católica (FREYRE, 2000, p.32-95; 2003, p.109-156). Esta se definiu em favor menos da austeridade na observação das doutrinas e preceitos intelectuais e, bem mais, nas comunicações místicas diretas envolvendo outras vertentes religiosas, em particular, os cultos afrobrasileiros (BASTIDE, 1985, p.47-84). Diríamos mais marcadamente materialista, a participação da esfera religiosa na coordenação das relações sociais favoreceu o apego às conjunturas em detrimento daquela sistematização ética dos atos, descrita por Max Weber (2006, p.73-88) ao tratar das religiões universais. Logo, em confluência com o domínio exercido pelos poderes locais, o advento de microracionalidades pactuou com modos comportamentais descontínuos entre si, deixando ampla margem para o despojamento das atitudes em meio ao caráter híbrido de zonas de convivência nas quais se deixam livre os trânsitos da intimidade para o público e vice-versa.

Por outro lado, os ajustes formais e semânticos internos ao formato dos festivais popular de massa desautorizam os provincianizar como símbolos inequívocos de um pertencimento tanto autóctone quanto autorreferente, seja ele local/regional e/ou nacional. Pelo contrário, convoca-nos pensar em transitividades plasmadas na espacialidade provisória do tempo extraordinário da festividade. Sinalizam na direção dessas reorientações, os debates travados em torno do equilíbrio entre a 


\section{Transitividades nos Circuito e Cenários das Festas Espetáculos \\ Populares}

preservação e transmissão dos sentidos de lugar e de posicionamentos críticos, na medida em que se concebem as festas como fulcros do elo de tradições com a afirmação de identidades coletivas, e o incremento da inserção de celebrações referidas a locais e temas os mais distintos nos círculos monetário-financeiro das mídias e do turismo (SANT'ANNA, 2013, p.21-30). Deixa-se patente a conciliação, ainda que tensa, de expressões lúdicas, profanas e religiosas, com os requisitos da sociedade de consumidores respaldada no padrão de socialidade da estrutura urbanoindustrial e de serviços.

Se o tramado da economia do lúdico evidencia, portanto, o cruzamento entre dinâmicas histórico-civilizatórias, nas quais sociedadenação, modernidade e entretenimento se fizeram mútuos, também é verdade que sugere possibilidades de entender como as festas espetáculos populares se consagraram importantes fóruns de visibilização de imagens pessoais e institucionais, na medida em que atraem, aglutinam e o colocam em interdependências espectros sociohumanos heterogêneos. Fator este que as tornam objetos de disputas várias, envolvendo desde corporações empresariais, passando por instâncias estatais e chegando a entidades civis (associações representantes de categorias sociais, ONGs, bandas musicais, artistas solistas, entre outros).

O imã inerente ao formato desses grandes festivais populares parece estar na cumplicidade estabelecida entre o fazer divertido, promotor do prazer, com seus apelos sensórios e os afetos acionados e difundidos, assim, gerando sentimentos nessas ocasiões de congraçamento lúdicoestético. Diria, portanto, que a forma festiva espetacular engendra as afetividades e, neste movimento, tanto lhes confere visibilidade, fazendo-as discerníveis e possíveis de compor as trocas públicas dos significados pelas quais se realiza a produção e circulação social dos sentidos nesse circuito do entretenimento. Ao mesmo tempo, ao aderir à funcionalidade lúdicoestética e comunicativa, a gradação cromática da textura dos afetos envolvidos materializa os sentidos na tessitura dos corpos. Chamamos de mimese sensório-cromática essa modalidade de prática lógica²; mimese,

2 Tomamos emprestado a Pierre Bourdieu (2009, p. 152) a noção de prática lógica. Entendemos por esta um movimento temporal cuja natureza perfomativa consiste no desdobramento de atos que, a um só tempo, potencializam e constituem esquemas de ser, saber e fazer incorporados pelos corpos em processos contínuos de aprendizagem históricoculturais. 
Edson Farias

porque ela corresponde atos de criação de significados a partir de implicações mútuas com sentidos anteriores.

Possível, em grande medida, graças aos diversos trânsitos locais/regionais, nacionais, internacionais e transnacionais, as festas espetáculos populares implicam, no instante em que acomodam no seu formato orientado pela mimese sensório-cromática, pessoas, ideias, técnicas, tecnologias e objetos. Com isso, o modo de simbolização em que se constitui esse gênero sociocultural conjumina o que, a princípio, está distante sociocultural e/ou geograficamente. Dessa maneira, deparamos com paisagens nos festivais populares em que, como nos palcos armados na região do Recife Velho, durante o carnaval, a melodiosa sinfonia metálica do frevo faz dueto com os acordes atonais do rock'in roll (SANDRONI, 2013, p.71-8). Tão provável é encontrar, ainda, o rústico da chita, que veste as quadrilhas matutas, contornar as indumentárias de cores ácidas fosforescentes usadas pelas bandas de forro eletrônico ou de tecnobrega paraense em oportunidades vicejadas no amplo ciclo junino nordestino (CHIANCA, 50-58). Ver o encontro, ao som de bandas musicais de pagode, da vaquejada sertaneja brasileira com os signos da cultura country estadunidense durante o circuito de rodeios tendo por núcleo aquele realizado na cidade de Barretos, no interior do estado de São Paulo (FAGNANI, 2013). Como também ser fisgado pela percussão dos atabaques ambientando um solo de balé clássico, sob um trio-elétrico na folia soteropolitana (GUERREIRO, 2000). Exemplos assim poderiam se replicar aos montes. Simultaneamente, o mesmo operador prático-lógico da mimese sensório-cromática suscita combinações inimagináveis em outros contextos, como aquela em que se tornam próximos a parafernália de uma "balada" gay com a procissão católica no carnaval devoto do Círio de Nazaré, em Belém do Pará (MATTOS, 2014, p.200-204; NEGRÃO, 2012, p.95-109). Ou, ainda, subjaz à aliança inusual pela qual se fazem afins a multitonalidade da arte plumária ameríndia do futurismo metálico dos personagens da ficção científica cinematográfica hollywoodiana, no Festival Folclórico dos Bois-bumbás de Parintins, no Amazonas (SILVA, 2013, p.113-120).

Por certo, as festas espetáculos populares não compõem a esfera da política, mas nada impede que nelas se façam políticas referidas às mais diferentes representações de questões. Ilustrativo é o que aconteceu no último carnaval, durante o desfile da escola de samba Mocidade Independente de Padre Miguel, no Sambódromo carioca. Já que o enredo 
Transitividades nos Circuito e Cenários das Festas Espetáculos Populares

retratava a multiplicidade cultural pernambucana, um dos carros alegóricos tematizou o forró em uma boite estilizada. Nele, nas laterais, havia imensas reproduções de casais de forrozeiros inspirados nos bonecos de barro do mestre Vitalino. Entre os casais que dançavam estavam o composto por dois homens se beijando. Nesse sentido, podemos concluir a possibilidade da festa espetáculo popular promover o trânsito entre a esfera da política e da cultura. Ou seja, viabiliza a comunicação daquele espaço em que são vocalizados interesses e onde as decisões tomadas repercutem sobre a vida pública e privada com o outro, no qual se dá a nomeação e significação a tudo quanto reclama visibilidade pública. Mas algo assim se faz na medida mesma em que são requisitadas inovações comportamentais para os naipes de novidades mobilizados na comunicação lúdico-estética. A reflexividade social promovida, em meios aos enquadramentos feitos nos comentários que se depreendem dos gestos e indumentárias, das canções e cenografias, também das rodas de conversa, atende uma pauta obediente ao critério principal de divertir.

Para finalizar, o que ainda merece maior atenção analítica é: como, constituídos os elencos de questões que poderão render à festa a natureza de forma social de uma diferença cultural, são as festas espelhos refletores de outros sistemas sociais ou elaboram sentidos próprios, mas que serão vivenciados na temporalidade ordinária?

Antes, chamamos atenção para o fato de que, no instante em que as festas espetáculos garantem espaciotemporalidades em que a busca de oportunidades eufóricas se torna possível pela interdição dos fatores que fazem da rotina diária algo moroso e disperso, para os cenários que compõem o circuito desses acontecimentos um amplo e heterogêneo contingente humano. Afinal, estão abertas as possibilidades para interesses os mais diversos obterem plasticidade e, logo, adquirirem contornos mais diferenciados e individualizados. Uma conclusão que deriva é o quanto as festas espetáculos, ao serem identificadas como espaço de visibilização de imagens, passam a ser objetos concorridos, porque nelas se vislumbra meios de tornar tangíveis a invisibilidade dos anseios e demandas vinculadas à procura de tudo aquilo hábil em atender e satisfazer demandas. Enfim, as festas espetáculos são elevadas ao status de fóruns em que os sentimentos mais autênticos da pessoa podem aflorar e obter reconhecimento. Contudo, neste mesmo andamento, o exercício de individualização/diferenciação requer a silenciosa formatação das 
Edson Farias

múltiplas e plurais finalidades em imagens cujos protocolos de comunicação seguem a prática lógica da mimese sensório-cromática; assim, primam pela manutenção da forma festiva em sua alegre e leviana diferencialidade. Através dos mesmos e variados canais que levam os subsídios informando de significados às ambiências festivas, já reelaborados como signos festivos, os mesmos significados incrementam as reflexividades cotidianas e são fundamentais na instauração de situações como as da parada gay, na cidade de São Paulo. Ali, mostram-se tênues os limites entre a passeata comprometida com a representação público-política da comunidade LGBT, parte da luta pela conquista e afirmação da cidadania dos seus membros, e a irreverência multicromática do carnaval fora de época sobre o asfalto da Avenida Paulista.

\section{Bibliografia}

BACK, Ulrich. "A Reinvenção da política: rumo a uma teoria da modernização reflexiva" IN: GIDDENS, Anthony, BACK, Ulrich, LASH, Scott: Modernização Reflexiva. São Paulo: Unesp, 1997.

BAKHTIN, Mikhail. A cultura popular na Idade Média e no Renascimento: o contexto de François Rabelais. 3a. ed. São Paulo/Brasília: Hucitec/UdUnb, 1996.

BASTIDE, Roger. As Religiões Africanas no Brasil. São Paulo: Pioneira, 1985.

BOURDIEU, Pierra. O Senso Prático. Petrópolis: Vozes, 2009.

CAVALCANTI, Bruno César. "Novos lugares da festa - tradições e mercado" IN: Dossiê Festa em Múltiplas Dimensões. Revista Observatório Itaú Cultural, n. 14, 2013.

CHIANCA, Luciana. "'O auxílio luxuoso da sanfona': tradição, espetáculo e mídia nos concursos de quadrilhas juninas" IN: Dossiê Festa em Múltiplas Dimensões. Revista Observatório Itaú Cultural, n. 14, 2013.

DA MATTA, Roberto. Ensaios de Antropologia Estrutural. Petrópolis (RJ): Vozes, 1973.

DA MATTA, Roberto. Universo do Carnaval: imagens e reflexões. Rio de Janeiro: Pinakotheke, 1981.

DA MATTA, Roberto. A Casa e a Rua. São Paulo: Brasilense, 1985.

FARIAS, Edson. "Humano demasiado humano: entretenimento, economia simbólica e forma cultural na configuração contemporânea do popular" IN: 
Transitividades nos Circuito e Cenários das Festas Espetáculos

Populares

FARIAS, Edson e MIRA, Maria Celeste (orgs.): Faces Contemporâneas da Cultura Popular. Jundiaí (SP): Paco, 2014.

FARIAS, Edson. "Festa da Metrópole" IN: RUBIM, Linda e MIRANDA, Nadja (orgas): Estudos da Festa. Salvador: EdUFBA, 2012.

FARIAS, Edson. Ócio e Negócio: festas populares e entretenimento-turismo no Brasil. Curitiba: Appris, 2011.

FARIAS, Edson. "A cultura popular na fisionomia da economia simbólica no Brasil". Teoria \& Pesquisa, vol. XVI n.01, jan./jun. 2007.

FARIAS, Edson. O Desfile e a cidade: o carnaval-espetáculo carioca. Rio de Janeiro: E-Papers, 2006.

FERREIRA, Felipe. Inventando Carnavais: o surgimento do carnaval carioca no século XIX e outras questões carnavalescas. Rio de Janeiro: Editora da UFRJ, 2005.

FREYRE, Gilberto. China Tropical e Outros Escritos sobre a Influência do Oriente na Cultura Luso-Brasileira. Brasília: EdUnB - São Paulo: Imprensa Oficial do Estado, 2003.

FREYRE, Gilberto. Sobrados e Mucambos: Decadência do patriarcado rural e desenvolvimiento do urbano. Rio de Janeiro: Record, 2000.

GUERREIRO, Goli. Tramas de Tambores. São Paulo: 34, 2000.

GUMBRECHT, Hans Ulrich. Elogio da Beleza Atlética. São Paulo: Cia das Letras, 2007.

LASCH, Scott. "A reflexão e seus duplos: estrutura, estética e comunidade" IN: GIDDENS, Anthony, BACK, Ulrich, LASH, Scott: Modernização Reflexiva. São Paulo: Unesp, 1997.

LEOPOLDI, José Sávio. "Escolas de samba, blocos e o renascimento da carnavalização". Textos Escolhidos de Culturas e Arte Populares, Rio de Janeiro, vol. 7 n.2.

KELLNER, Douglas. "Popular Culture and the Construction of Postmodern Identities" in: Scott Lash e Jonathan Friedman (org.), Modernity and Identity. Oxford/Cambridge (Mass.): Blackwell, 1993.

MATTOS, Lucília da Silva. "Belém em festa: a economia do lúdico da fé no Círio de Nazaré" IN: FARIAS, Edson e MIRA, Maria Celeste (orgs.): Faces Contemporâneas da Cultura Popular. Jundiaí (SP): Paco, 2014.

MOURA, Milton. "Êxtase e euforia: um binômio estratégico para a compreensão histórica do carnaval contemporâneo" IN: Dossiê Festa em Múltiplas Dimensões. Revista Observatório Itaú Cultural, n. 14, 2013. 
Edson Farias

NEGRÃO, Keyla. "'Arraial do arraial da pavulagem': cultura da festa, saberes populares e espetáculo na Amazônia paraense" IN: RUBIM, Linda e MIRANDA, Nadja (orgas): Estudos da Festa. Salvador: EdUFBA, 2012.

NOBREGA, Zulmira. "A festa do maior São João do Mundo" IN: RUBIM, Linda e MIRANDA, Nadja (orgas): Estudos da Festa. Salvador: EdUFBA, 2012.

MOTTA, Aydano André. Blocos de Rua do Carnaval do Rio de Janeiro. Rio de Janeiro: Reptil, 2013.

PAULA, Silvana G. "Quando o campo se torna uma experiência urbana: o caso do estilo de vida country no Brasil". Estudos Sociedade e Agricultura, n.17 outubro de 2001.

QUEIROZ, Maria Isaura P. Carnaval Brasileiro: o vivido e o mito. São Paulo: Brasiliense, 1992.

SANDRONI, Carlos. "'...Do frevo e do maracatu’: música e festa no carnaval de Pernambuco". IN: Dossiê Festa em Múltiplas Dimensões. Revista Observatório Itaú Cultural, n. 14, 2013.

SANT'ANNA, Márcia. "A festa como patrimônio cultural: problemas e dilemas da salvaguarda" IN: Dossiê Festa em Múltiplas Dimensões. Revista Observatório Itaú Cultural, n. 14, 2013.

SENNETT, Richard. A Cultura do Novo Capitalismo. Rio de Janeiro: Record, 2006.

SENNETT, Richard. O Declínio do Homem Público: as tiranias da intimidade. São Paulo: Cia das Letras, 1988.

SILVA, José Maria da. "Festas e identidades na Amazônia" IN: Dossiê Festa em Múltiplas Dimensões. Revista Observatório Itaú Cultural, n. 14, 2013.

WEBER, Max. Sociologia das Religiões. Lisboa: Relógio D’água, 2006.

WOUTERS, Cas. "Como os processos civilizadores continuaram: rumo a uma informalização dos comportamentos e a uma personalidade de terceira natureza" IN: FARIAS, Edson e LEÃO, Andréa Borges (orgs.): Dossiê Norbert Elias. Sociedade e Estado, vol. 27, n.03 set./dez. 2012.

Enviado em: 20/07/2016

Aceito em: 18/09/2016 